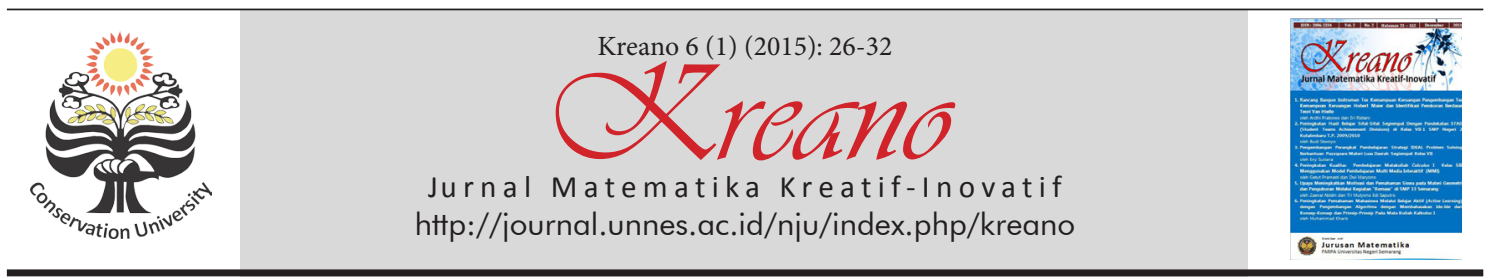

\title{
Studi Perbedaan Keefektifan Pembelajaran LC-5E dan CIRC Terhadap Kemampuan Pemecahan Masalah Matematika
}

\author{
Sulastri, E. ', Mariani, S. ' , dan Mashuri' \\ 'Jurusan Matematika Fakultas MIPA Universitas Negeri Semarang \\ Email: 1astry_azka@yahoo.com
}

DOI: http://dx.doi.org/10.15294/kreano.v6i1.4452

Received : August 2015; Accepted: September 2015; Published: September 2015

\begin{abstract}
Abstrak
Tujuan penelitian ini adalah membandingkan keefektifan model pembelajaran kooperatif tipe LC-5E (Learning Cycle $\left.{ }_{5} \mathrm{E}\right)$ dan tipe CIRC (Cooperative Integrated Reading and Composition) terhadap kemampuan pemecahan masalah matematika peserta didik. Populasi penelitian adalah peserta didik kelas X SMA Negeri 2 Ungaran. Sampel diambil secara cluster random sampling. Data akhir mengenai kemampuan pemecahan masalah peserta didik diambil menggunakan metode tes. Teknik analisis data menggunakan uji proporsi, uji Anava dan uji lanjut LSD. Hasil penelitian menunjukkan kelas yang dikenai perlakuan pembelajaran LC-5E dan CIRC mencapai ketuntasan belajar. Dari uji Anava diketahui bahwa ada perbedaan rata-rata yang signifikan. Selanjutnya dilakukan uji lanjut LSD menunjukkan Kelompok Eksperimen 1 paling baik. Simpulan dari penelitian ini adalah model pembelajaran LC-5E lebih efektif dibandingkan tipe CIRC terhadap kemampuan pemecahan masalah peserta didik. Saran yang dapat direkomendasikan adalah pembelajaran LC-5E dapat digunakan sebagai alternatif dalam mengembangkan kemampuan pemecahan masalah peserta didik.
\end{abstract}

\begin{abstract}
The purpose of this research was to compare the effectiveness of cooperative learning models type LC-5E (Learning Cycle 5E) and type CIRC (Cooperative Integrated Reading and Composition) toward students' mathematic problem solving ability. The population of this research was students grade X of SMA Negeri 2 Ungaran.The samples were taken by cluster random sampling. The final data about students' problem solving ability were taken used test method. Data were analysed used propotion test, ANOVA test, and LSD test. The result shown that classes that given LC-5E and CIRC learning models achieved mastery learning. From ANOVA test known that the averages are different significantly. From $L S D$ test is known that the experiment group was the best. The conclusions from this research are $L C-5 E$ is more effective than CIRC learning model toward students' problem solving ability. The suggestion is $L C-5 E$ model can be used as an alternative to develope stundents' problem solving ability.
\end{abstract}

Keywords: CIRC (Cooperative Integrated Reading and Composition); LC- 5 E (Learning Cycle 5 E); problem solving ability

\section{PENDAHULUAN}

Matematika merupakan ilmu yang mendasari perkembangan teknologi modern, mempunyai peranan penting dalam berbagai disiplin ilmu dan memajukan daya pikir manusia. Penguasaan matematika sejak dini diperlukan untuk menguasai dan menciptakan teknologi di masa depan. Salah satu tujuan belajar matematika bagi peserta didik adalah agar ia mempunyai kemampuan atau keterampilan dalam memecahkan masalah atau soal-soal matematika, sebagai sarana baginya untuk mengasah penalaran yang cermat, logis, kritis, dan kreatif. Oleh karena itu, kemampuan pemecahan masalah menjadi fokus pembelajaran matematika di semua jenjang.

NCTM (2000) menyebutkan bahwa memecahkan masalah bukan saja merupakan suatu sasaran belajar matematika, tetapi sekaligus merupakan alat utama untuk melakukan belajar itu. Oleh karena itu, kemampuan pemecahan masalah menjadi fokus pembela- 
jaran matematika di semua jenjang, dari sekolah dasar hingga perguruan tinggi. Dengan mempelajari pemecahan masalah di dalam matematika, peserta didik akan mendapatkan cara-cara berpikir, kebiasaan tekun, dan keingintahuan, serta kepercayaan diri di dalam situasi-situasi tidak biasa, sebagaimana situasi yang akan mereka hadapi di luar kelas matematika (Widjajanti, 2009).

Hasil studi pendahuluan yang dilaksanakan pada salah satu sekolah negeri di kabupaten Semarang menunjukkan bahwa masih banyak peserta didik masih kesulitan dalam mengerjakan soal pada materi jarak dalam dimensi tiga kelas X. Banyak peserta didik yang tidak menerapkan langkah-langkah pemecahan masalah dengan tepat. Bahkan masih ada peserta didik yang tidak bisa mengerjakan soal sama sekali. Oleh karena itu, perlu adanya upaya untuk mengembangkan kemampuan pemecahan masalah peserta didik. Namun, secara realita pemecahan masalah merupakan kegiatan matematika yang sangat sulit dilaksanakan baik bagi guru yang mengajarkan maupun bagi peserta didik yang mempelajarinya. Sifat inilah yang perlu disadari dan dicari jalan keluar sehingga peserta didik dapat memecahkan masalah matematika dengan mudah dan menyenangkan.

Pengembangan kemampuan pemecahan masalah peserta didik dapat dilakukan dengan menerapkan pembelajaran kooperatif. Pembelajaran kooperatif merupakan model pembelajaran dengan cara berkelompok untuk bekerja sama saling membantu mengkonstruksi konsep, menyelesaikan persoalan, atau inkuiri guna mencapai tujuan pembelajaran. Ragam model pembelajaran kooperatif cukup banyak di antarnya Learning Cycle $5 E$ (LC-5E) dan Cooperative Integrated Reading and Composition (CIRC).

LC-5E adalah model pembelajaran yang berpusat pada peserta didik berupa rangkaian tahap-tahap kegiatan (fase) yang diorganisasi dengan baik sehingga peserta didik dapat menguasai kompetensi-kompetensi yang harus dicapai dalam pembelajaran. Menurut Wena (2009) fase dalam LC- $5 \mathrm{E}$ yaitu engagement, exploration, explanation, elaboration, dan evaluation. LC $-5 \mathrm{E}$ memfasilitasi peserta didik untuk belajar secara efektif dan meng- organisasikan pengetahuan yang diperoleh sehingga dapat bertahan lebih lama.

CIRC termasuk salah satu tipe model Cooperative Learning. Pada awalnya, model CIRC diterapkan dalam pembelajaran Bahasa. Menurut Sutarno (2010), Cooperative Integrated Reading and Composition (CIRC) dibagi menjadi beberapa fase, yaitu: (1) fase orientasi; (2) fase organisasi; (3) fase pengenalan konsep; (4) fase publikasi; dan (5) fase penguatan dan refleksi.

Hasil penelitian Tuna \& Ahmet (2013) menunjukkan bahwa skor prestasi akademik dan pengetahuan trigonometri Kelompok Eksperimen lebih tinggi dari pada Kelompok Kontrol. Sedangkan menurut hasil penelitian dari Cahyaningrum (2012) menyebutkan bahwa hasil belajar peserta didik dalam kemampuan pemecahan masalah dengan menggunakan model pembelajaran CIRC berbantuan LKS rekreatif dapat mencapai ketuntasan klasikal lebih dari 75\% dan rata-rata hasil belajarnya lebih baik dari pada rata-rata hasil belajar peserta didik dengan menggunakan pembelajaran ekspositori.

Berdasarkan latar belakang di atas, maka rumusan masalah yang diangkat dalam penelitian ini adalah (1) apakah model pembelajaran kooperatif tipe LC- 5 E efektif terhadap kemampuan pemecahan masalah peserta didik kelas $X_{i}(2)$ apakah model pembelajaran kooperatif tipe CIRC efektif terhadap kemampuan pemecahan masalah peserta didik kelas $X_{i}$ dan (3) apakah ada perbedaan antara model pembelajaran LC-5E dan CIRC terhadap kemampuan pemecahan masalah peserta didik kelas $X$.

Menurut Sinambela (2008) pembelajaran dikatakan efektif apabila mencapai sasaran yang diinginkan, baik dari segi tujuan pembelajaran maupun prestasi peserta didik yang maksimal. Tujuan penelitian secara umum adalah untuk mengetahui apakah model pembelajaran LC-5E lebih efektif dibandingkan dengan model pembelajaran CIRC terhadap kemampuan pemecahan masalah peserta didik.

\section{METODE}

Metode penelitian yang digunakan dalam penelitian ini adalah metode eksperimen den- 
gan desain posttest-only control design (Sugiyono, 2010). Pada penelitian ini terdapat tiga kelompok yaitu Kelompok Eksperimen 1, Kelompok Eksperimen 2, dan Kelompok Kontrol. Pada Kelompok Eksperimen 1 dikenai pembelajaran dengan model pembelajaran LC-5E, Kelompok Eksperimen 2 pembelajaran menggunakan model pembelajaran CIRC, dan Kelompok Kontrol menggunakan model pembelajaran ekspositori. Penilaian kemampuan awal dilakukan dengan mengambil data ulangan harian bab sebelumnya yaitu trigonometri. Setelah dilakukan pembelajaran dengan kedua model tersebut maka ketiga kelompok diberikan posttest untuk mengukur kemampuan pemecahan masalah.

Subjek penelitian ini adalah peserta didik kelas X SMA Negeri 2 Ungaran yang terdiri dari sebelas kelas yaitu X.1, X.2, X.3, X.4, X.5, X.6, X.7, X.8, X.9, X.10, dan X.11. Teknik pengambilan sampel yang digunakan berupa cluster sampling (Arikunto, 2010) yang menghasilkan peserta didik kelas X.3 sebagai Kelompok Eksperimen 1 yang dikenai perlakuan model pembelajaran LC-5E, peserta didik kelas X.2 sebagai Kelompok Eksperimen 2 yang dikenai perlakuan model pembelajaran CIRC, dan peserta didik kelas X.1 sebagai Kelompok Kontrol yang dikenai perlakuan model pembelajaran Ekspositori.

Variabel yang akan menjadi fokus penelitian adalah kemampuan pemecahan masalah peserta didik. Teknik pengambilan data menggunakan metode dokumentasi untuk memperoleh data awal peserta didik dan metode tes untuk memperoleh data kemampuan pemecahan masalah peserta didik setelah dikenai model pembelajaran. Adapun instrumen yang digunakan adalah tes pemecahan masalah dalam bentuk uraian.

Sebelum peneliti melaksanakan pembelajaran pada Kelompok Eksperimen, maka terlebih dahulu dilakukan analisis data awal yaitu uji normalitas, uji homogenitas, dan uji kesamaan tiga rata-rata (Sudjana, 2005). Analisis data awal dilakukan untuk mengetahui bahwa kelompok sampel mempunyai kemampuan awal yang sama. Setelah itu, model pembelajaran diterapkan pada Kelompok Eksperimen. Pada akhir pertemuan, tes kemampauan pemecahan masalah diberikan kepada ketiga kelompok sampel. Hasil tes kemampuan pemecahan masalah dihitung menggunakan uji kesamaan tiga rata-rata dengan ketentuan jika data akhir berdistribusi normal dan homogen, maka menggunakan uji Anava dan apabila data akhir tidak berdistribusi normal, maka menggunakan uji Anava satu jalan Kruskal Walls. Jika terdapat perbedaan, maka dilanjutkan perhitungan menggunakan uji lanjut LSD untuk mengetahui kelompok mana yang menunjukkan perbedaan paling signifikan. Uji proporsi digunakan untuk mengetahui ketuntasan klasikal peserta didik kelompok sampel. Dalam penelitian ini ditetapkan ketuntasan individu sebesar 70 sedangkan ketuntasan secara klasikal sebesar lebih dari sama dengan $75 \%$ sesuai dengan persen KKM ideal menurut BSNP (2009).

\section{HASIL DAN PEMBAHASAN}

Analisis data awal menunjukkan bahwa data nilai ulangan harian bab sebelumnya yaitu bab Trigonometri yang mencakup mencakup materi pokok perbandingan, fungsi, persamaan, dan identitas trigonometri dari peserta didik kelas X SMA Negeri 2 Ungaran berdistribusi normal, variansnya homogen, dan memiliki rata-rata yang relatif sama. Berdasarkan analisis tersebut, peneliti dapat melakukan eksperimen pada kelas sampel.

Penelitian ini diawali dengan pelaksanaan pembelajaran pada ketiga kelas dengan materi jarak dalam dimensi tiga. Pada akhir pembelajaran, ketiga kelas dilakukan tes untuk mengetahui kemampuan pemecahan masalah peserta didik. Tes dilakukan pada Kelompok Eksperimen 1, Kelompok Eksperimen 2 dan Kelompok Kontrol dengan soal yang sama. Soal tes evaluasi tersebut adalah tes tertulis berbentuk uraian sebanyak tujuh butir soal dengan alokasi waktu 90 menit. Sebelum tes diberikan soal tes terlebih dahulu diuji cobakan untuk mengetahui validitas, reliabilitas, daya pembeda, dan tingkat kesukaran (Arikunto, 2007) dari tiap-tiap butir tes pada kelas uji coba. Dalam penelitian ini, soal tes evaluasi yang digunakan pada Kelompok Eksperimen 1, Kelompok Eksperimen 2 dan Kelompok Kontrol sudah memenuhi syarat. sehingga soal tes tersebut dapat dikatakan 
Tabel 1. Deskripsi Hasil Tes Pemecahan Masalah

\begin{tabular}{llccc}
\hline No & Statistik Deskriptif & $\begin{array}{c}\text { Kelompok } \\
\text { Eksperimen 1 }\end{array}$ & $\begin{array}{c}\text { Kelompok } \\
\text { Eksperimen 2 }\end{array}$ & $\begin{array}{c}\text { Kelompok } \\
\text { Kontrol }\end{array}$ \\
\hline 1 & Banyak peserta didik & 34 & 34 & 34 \\
2 & Nilai tertinggi & 95 & 95 & 85 \\
3 & Nilai terendah & 66 & 57 & 48 \\
4 & Rata-rata & 79,88 & 74,62 & 68,32 \\
5 & Varians & 54,17 & 59,64 & 89,92 \\
6 & Simpangan baku & 7,36 & 7,72 & 9,48 \\
\hline
\end{tabular}

Tabel 2. Hasil Uji Normalitas Tes Pemecahan Masalah Kelompok Sampel

\begin{tabular}{lllcl}
\hline \multirow{2}{*}{ No } & Kelompok Sampel & $\chi_{\text {hitung }}^{2}$ & $\chi_{\text {tabel }}^{2}$ & Kriteria \\
\hline 1 & Eksperimen 1 & 5,87 & 7,81 & Berdistribusi normal \\
2 & Eksperimen 2 & 5,40 & 7,81 & Berdistribusi normal \\
3 & Kontrol & 0,22 & 7,81 & Berdistribusi normal \\
\hline
\end{tabular}

baik untuk mengukur kemampuan pemecahan masalah peserta didik kelas X SMA Negeri 2 Ungaran. Setelah diberikan tes kemampuan pemecahan masalah, diperoleh nilai peserta didik yang kemudian dianalisis.

Setelah melakukan perlakuan yang berbeda-beda pada masing-masing kelas, selanjutnya diperoleh data hasil tes kemampuan pemecahan masalah peserta didik pada tabel 1.

Berdasarkan hasil tes kemampuan pemecahan masalah peserta didik pada Tabel 1, selanjutnya dapat dilakukan uji hipotesis. Langkah pertama yaitu uji normalitas sebagaimana hasilnya dapat dilihat dalam tabel 2.

Berdasarkan Tabel 2 dapat disimpulkan bahwa data hasil tes kemampuan pemecahan masalah peserta didik berdistribusi normal. Selanjutnya dilakukan uji homogenitas menggunakan uji Bartlet. Dari hasil perhitungan diperoleh hasil $\chi_{\text {hitung }}^{2}=2,48$ dan $\chi_{\text {tabel }}^{2}$ dengan $\alpha=$ $5 \%$ adalah 5,99. Karena $\chi_{\text {hitung }}^{2}<\chi_{\text {tabel, }}^{2}$ maka $\mathrm{H}_{\mathrm{o}}$ diterima, sehingga dapat disimpulkan bahwa sampel homogen.

Selanjutnya dilakukan uji hipotesis. Uji hipotesis pertama yaitu uji ketuntasan belajar yang dilakukan menggunakan uji pihak kanan (Sudjana, 2005). Uji digunakan ini untuk mengetahui apakan kelas yang diberi perlakuan telah mencapai ketuntasan belajar klasikal yaitu minimal $75 \%$ peserta didik telah mencapai nilai lebih dari atau sama dengan 70. Dari hasil perhitungan untuk Kelompok Eksperimen 1

diperoleh. Nilai maka $\mathrm{H}_{0}$ ditolak. Sedang- kan perhitungan untuk Kelompok Eksperimen 2 diperoleh. Nilai maka $\mathrm{H}_{\mathrm{o}}$ ditolak pula. Artinya, hasil tes kemampuan pemecahan masalah peserta didik Kelompok Eksperimen 1 yang dikenai model pembelajaran $\mathrm{LC}-5 \mathrm{E}$ dan Kelompok Eksperimen 2 yang dikenai model pembelajaran CIRC telah mencapai ketuntasan belajar secara klasikal. Dengan kata lain, hipoteis 1 dan 2 dipenuhi.

Uji hipotesis selanjutnya adalah untuk mengetahui apakah ada perbedaan yang signifikan di antara ketiga kelas sampel. Berdasarkan hasil analisis sebelumnya diperoleh bahwa data hasil tes kemampuan pemecahan asalah peserta didik berdistribusi normal dan variansnya homogen. Oleh karena itu, uji kesamaan tiga rata-rata yang digunakan adalah one way anova (Anava satu jalan). Berdasarkan perhitungan Anava diperoleh $F_{\text {hitung }}=16,77$ sedangkan $F_{\text {tabel }}$ dengan $\alpha=5 \%$ dan dk pembilang $=2$ serta $\mathrm{dk}$ penyebut $=98$ adalah 3,08. Karena $F_{\text {hitung }}>F_{\text {tabel' }}$ maka $\mathrm{H}_{\mathrm{o}}$ ditolak sehinga dapat disimpulkan bahwa terdapat perbedaan rata-rata dari ketiga kelas tersebut. Jika $\mathrm{H}_{\text {。 }}$ pada Anava ditolak, maka uji lanjut dapat dilakukan. Uji lanjut dalam penelitian ini berguna untuk mengetahui pasangan nilai ratarata yang perbedaannya signifikan. Dalam penelitian ini menggunakan uji LSD. Dari perhitungan diperoleh hasil tabel 3.

Berdasarkan Tabel 3 diperoleh rata-rata nilai tes pemecahan masalah peserta didik yang berbeda signifikan adalah Eksperimen 1 dan Kontrol, Eksperimen 2 dan Kontrol, Eks- 
Tabel 3. Hasil uji lanjut LSD

\begin{tabular}{llll}
\hline \multicolumn{1}{c}{ Kelompok sampel } & $\begin{array}{c}\text { Selisih } \\
\text { Rata-rata }\end{array}$ & LSD & Simpulan \\
\hline Kelompok Eksperimen 1 dan Kelompok Eksperimen 2 & 5,2048 & 3,965 & Rata-rata berbeda signifikan \\
Kelompok Eksperimen 1 dan kelompok control & 11,4989 & 3,965 & Rata-rata berbeda signifikan \\
Kelompok Eksperimen 2 dan kelompok control & 6,2941 & 3,965 & Rata-rata berbeda signifikan \\
\hline
\end{tabular}

perimen 2 dan Eksperimen 1. Pada Tabel 1 diperoleh bahwa rata-rata nilai tes pemecahan masalah pada Kelompok Eksperimen 1 lebih baik dari Kelompok Eksperimen 2 dan rata-rata nilai tes pemecahan masalah pada Kelompok Eksperimen 2 lebih baik dari Kelompok Kontrol. Jadi Kelompok Eksperimen 1 terbaik di antara ketiganya. Atau dengan kata lain bahwa model pembelajaran kooperatif tipe LC-5E paling baik daripada model pembelajaran kooperatif tipe CIRC dan ekspositori terha

dap kemampuan pemecahan masalah peserta didik kelas $X$ pada materi jarak dalam dimensi tiga.

Dalam proses pembelajaran Kelompok Eksperimen 1, peserta didik diberi perlakuan dengan model pembelajaran LC-5E. Sesuai yang disebutkan Wena (2009) bahwa terdapat 5 fase dalam menerapkan model pembelajran LC-5E. fase pertama yaitu Engagement, di mana guru memotivasi peserta didik untuk membangkitkan minat dan keingintahuan mereka terhadap materi yang akan dipelajari. Fase kedua yaitu Exploration, di mana peserta didik dikelompokkan menjadi beberapa kelompok yang heterogen dan kemudian guru memberikan lembar kerja peserta didik untuk didiskusikan secara kelompok. Fase ketiga yaitu Explanation, di mana salah satu anggota kelompok yang ditunjuk oleh guru mempresentasikan model matematika yang digunakan untuk menyelesaikan masalah di depan kelas dan kelompok lainnya menanggapi hasil presentasi tersebut. Fase keempat yaitu Elaboration, dimana peserta didik diberi kesempatan untuk menerapkan konsep dan ketrampilan yang telah dipelajari dalam konteks yang berbeda, sehingga peserta didik dapat mengaplikasikan konsep baru tersebut dalam situasi baru. Dan fase yang kelima yaitu Evaluation, untuk mengetahui sejauh mana pemahaman atau pengetahuan peserta didik dalam menerapkan konsep baru dengan memberikan kuis di akhir pembelajaran pada setiap pertemuan.

Kesulitan yang dialami peserta didik pada tahap Exploration, dimana peserta didik berdiskusi untuk mengerjakan soal yang terdapat dalam LKPD. Pada tahap ini peserta didik mengalami kesulitan dalam menjawab pertanyaan yang terdapat dalam LKPD. Hal ini dimungkinkan karena peserta didik belum menguasai konsep yang telah dipelajari sebelumnya, salah satunya materi pokok ketegaklurusan. Sehingga, ketika diskusi peneliti aktif berkeliling untuk memberikan penjelasan, memantau jalannya diskusi dan membimbing kelompok yang mengalami kesulitan.

Pada tahap Explanation, salah satu perwakilan kelompok mempresentasikan hasil diskusinya di depan kelas. Pada tahap ini peserta didik yang bertugas maju ke depan kelas untuk mempresentasikan hasil diskusinya masih enggan untuk maju ke depan kelas. Hal ini dimungkinkan karena rasa percaya diri peserta didik masih rendah. Sehingga guru perlu memotivasi peserta didik agar berkenan untuk mempresentasikan hasil diskusi kelompoknya di depan kelas dengan penuh rasa percaya diri dan peserta didik lainnya menanggapi hasil diskusi kelompok yang telah dipresentasikan.

Pada tahap Elaboration, yaitu peserta didik menerapkan konsep yang telah dipelajari dalam konteks yang berbeda. Pada tahap ini guru memberikan soal-soal yang bervariasi kepada peserta didik untuk dikerjakan secara berkelompok. Dalam tahap ini peserta didik membutuhkan waktu yang lama untuk menyelesaikan soal-soal yang telah diberikan. Hal ini dimungkinkan karena proses penyelesaian soal yang panjang sehingga membutuhkan waktu yang cukup lama untuk menyelesaikannya. Sehingga guru terpaksa harus mengurangi soal yang diberikan agar tidak membutuhkan waktu yang terlalu lama untuk menyelesaikannya.

Dalam proses pembelajaran Kelompok 
Eksperimen 2, peserta didik diberi perlakuan dengan model pembelajaran CIRC. Sesuai yang dikemukakan Sutarno (2010) bahwa terdapat 5 fase dalam menerapkan model pembelajaran CIRC. Fase pertama yaitu orientasi, di mana guru melaksanakan apersepsi dan pengetahuan awal peserta didik. Fase kedua yaitu organisasi, di mana guru membagi peserta didik ke dalam beberapa kelompok dengan memperhatikan keheterogenan akademik. Fase ketiga yaitu pengenalan konsep, di mana guru mengenalkan tentang konsep baru dengan bantuan lembar kerja peserta didik yang dibagikan pada setiap kelompok untuk didiskusikan. Fase keempat yaitu publikasi, di mana guru meminta anggota salah satu kelompok untuk mempresentasikan hasil diskusi di depan kelas. Dan fase terakhir yaitu penguatan dan refleksi yang dilakukan oleh guru bersama-sama dengan peserta didik.

Kesulitan yang dialami peserta didik pada tahap pengenalan konsep, dimana peserta didik berdiskusi untuk mengerjakan soal yang terdapat dalam LKPD hampir sama dengan kesulitan yang dialami peserta didik yang diberikan perlakukan model pembelajaran LC-5E pada tahap Exploration. Pada tahap ini peserta didik mengalami kesulitan dalam menjawab pertanyaan yang terdapat dalam LKPD. Hal ini karena peserta didik belum memahami dengan baik konsep yang telah dipelajari sebelumnya, salah satunya adalah materi pokok ketegak-lurusan. Sehingga, ketika diskusi peneliti aktif berkeliling memantau jalannya diskusi, menjelaskan dan membimbing kelompok yang mengalami kesulitan.

Pada tahap publikasi, salah satu perwakilan kelompok mempresentasikan hasil diskusinya di depan kelas hampir sama dengan kesulitan yang dialami peserta didik yang diberikan perlakukan model pembelajaran LC5 E pada tahap Explanation. Pada tahap ini peserta didik yang bertugas maju ke depan kelas untuk mempresentasikan hasil diskusinya masih enggan untuk maju ke depan kelas. Hal ini dimungkinkan peserta didik masih malu untuk unjuk gigi di depan kelas. Sehingga guru perlu memberikan motivasi yang lebih dan berinisiatif menunjuk secara acak peserta didik untuk maju ke depan agar peserta didik berkenan untuk mempresentasikan hasil dis- kusi kelompoknya dengan penuh rasa percaya diri dan peserta didik lainnya menanggapi hasil diskusi kelompok yang telah dipresentasikan.

Dalam proses pembelajaran ekspositori, guru menyampaikan materi, memberikan contoh soal, dan memberikan latihan soal. Berbeda dengan pembelajaran menggunakan model LC-5E dan CIRC, pada pembelajaran ekspositori peserta didik cenderung pasif dan bergantung pada guru. Peserta didik terkesan tidak mandiri karena hanya menunggu konfirmasi dari guru, tanpa rasa ingin tahu yang tinggi untuk menyelesaikan suatu masalah yang diberikan oleh guru. Pembelajaran terkesan monoton dan komunikasinya satu arah, karena guru mendominasi kegiatan pembelajaran dan peserta didik hanya berperan sebagai penerima informasi.

Kendala yang muncul pada Kelompok Kontrol adalah perhatian peserta didik terhadap penjelasan guru masih kurang maksimal. Hal ini terjadi dimungkinkan karena peserta didik merasa bosan dengan pembelajaran yang dipaparkan guru yang hanya secara lisan dan tulisan saja. Selain itu, juga muncul hambatan yaitu guru kurang maksimal dalam pemberian latihan soal yang bervariasi kepada peserta didik. Kesulitan lain yang dialami peserta didik adalah menyelesaikan soal yang diberikan oleh guru. Guru memberikan latihan soal yang bervariasi kepada peserta didik guna dikerjakan secara mandiri maupun kelompok akan tetapi kemudian membahasnya secara terpusat oleh guru. Hal ini terjadi karena keterbatasan waktu sehingga guru mencoba mengejar waktu dengan membahas latiahan soal secara terpusat.

Kesulitan yang dialami peserta didik secara umum yaitu menggambar dan memahami gambar bangun ruang yang disajikan. Masih ditemukan kesalahan peserta didik dalam menggambar bangun ruang. Peserta didik menggambarkan kubus dengan sudut surut lebih dari $45^{\circ}$. Mereka belum mengetahui bahwa untuk memperoleh gambar kubus yang baik, sudut surut yang digunakan sekitar $30^{\circ}$.

Berdasarkan hasil analisis data tes kemampuan pemecahan masalah peserta didik materi jarak dalam dimensi tiga dapat diketa- 
hui bahwa hasil tes peserta didik yang mendapat model pembelajaran kooperatif tipe LC5 E lebih tinggi dari pada hasil tes peserta didik yang dikenai model pembelajaran kooperatif tipe CIRC dan model pembelajaran ekspositori. Hal ini karena model LC-5E mempunyai lima siklus yang menuntut peserta didik untuk dapat mengeksplorasi pengetahuan secara mandiri sehingga materi yang dipelajari lebih mudah untuk dipahami. Namun, kendala dari model ini yaitu kekurangan waktu dalam mengerjakan LKPD dan latihan soal-soal sehingga saran yang dapat diajukan adalah pertanyaan dalam LKPD dan tugas peserta didik dibuat seminimal mungkin dengan indikator yang ingin dicapai termuat di dalamnya.

Dalam penelitian ini terdapat beberapa kelemahan, diantaranya adalah belum adanya pengamatan terhadap keaktifan peserta didik maupun keaktifan guru menggunakan lembar observasi. Sehingga peneliti tidak bisa menunjukkan bukti yang otentik mengenai kelemahan yang dialami peserta didik maupun guru. Peneliti hanya melakukan pengamatan secara subjektif.

\section{SIMPULAN}

Berdasarkan hasil penelitian dan pembahasan, maka dapat disimpulkan adalah: (1) penerapan model pembelajaran LC-5E efektif terhadap kemampuan pemecahan masalah matematika peserta didik kelas X SMA Negeri 2 Ungaran; (2) penerapan model pembelajaran CIRC efektif terhadap kemampuan pemecahan masalah matematika peserta didik kelas X SMA Negeri 2 Ungaran; dan (3) ada perbedaan keefektifan antara model pembelajaran LC-5E dan model pembelajaran CIRC yaitu model pembelajaran LC-5E lebih efektif dibandingkan dengan model pembelajaran CIRC terhadap kemampuan pemecahan masalah matematika peserta didik kelas X SMA Negeri 2 Ungaran.
Saran yang dapat diberikan adalah: (1) LKPD dan lembar diskusi peserta didik perlu direncakan secara matang agar alokasi waktu yang diberikan sesuai dengan kebutuhan peserta didik; (2) Penggelolaan kelas harus diperhatikan saat pelaksanaan model pembelajaran kooperatif tipe LC-5E maupun tipe CIRC terutama ketika sesi presentasi sebaiknya semua anggota kelompok diberikan tanggungjawab untuk dapat menjelaskan hasil diskusi kelompoknya dengan memberikan alokasi waktu tertentu.

\section{DAFTAR PUSTAKA}

Arikunto, S. (2007). Dasar-dasar Evaluasi Pendidikan. Jakarta: Bumi Aksara.

Arikunto, S. (2010). Prosedur Penelitian Suatu Pendekatan Praktik. Jakarta : Rineka Cipta.

BSNP. (2009). Buku Saku KTSP Sekolah Menengah Pertama. Jakarta: Departemen Pendidikan Nasional

Sinambela, P.N.J.M. (2008). Faktor-Faktor Penentu Keefektifan Pembelajaran dalam Model Pembelajaran Berdasarkan Masalah (Problem Based Instruction). Jurnal Penelitian. 1(2), 74-85.

Sudjana. (2005). Metoda Statistika. Bandung: PT Tarsito Bandung.

Sugiyono. (2007). Statistika untuk Penelitian. Bandung: AlfaBeta.

Sutarno, H., Enjang A.N. \& Indikhiro A. (2010). Penerapan Model Pembelaja-ran Cooperative Integrated Reading and Composition (CIRC) Berbasis Komputer untuk Meningkatkan Hasil Belajar Siswa pada Pembelajaran TIK. Jurnal Pendidikan Teknologi Informasi dan Komunikasi, 3(1), 1-5.

Tuna, A.K. \& Kacar, A. (2013). The Effect of 5 E Learning Cycle Model in Teaching Trigonometry On Students' Academic Achievement and the Permanence of Their Knowledge. International Journal on New Trends in Education and Their Implications. 4(1), Article: 07.

Wena, M. (2009). Strategi Pembelajaran Inovatif Kontemporer Suatu Tinjauan Konseptual Operasional. Jakarta: Bumi Aksara.

Widjajanti, D.B. (2009). Kemampuan Pemecahan Masalah Matematis Mahasiswa Calon Guru Matematika: Apa dan Bagaimana Mengembangkannya. Seminar Nasional FMIPA UNY. 